\title{
Corrigendum: Animal models in osteosarcoma
}

\section{Maria V. Guijarro*, C. Steve Ghivizzani and Parker C. Gibbs}

Musculoeskeletal and Oncology Lab, Orthopaedics and Rehabilitation, University of Florida, Gainesville, FL, USA

${ }^{*}$ Correspondence: mariavalle.gb@gmail.com

Edited by:

Sven Bilke, National Cancer Institute/National Institutes of Health, USA

Reviewed by:

Josh Waterfall, National Institutes of Health, USA

Terry Wu, National Institutes of Health, USA

Keywords: animal models, osteosarcoma, RB, conditional mouse models, germ-line mouse models, p53

\section{A corrigendum on}

Animal models in osteosarcoma

by Guijarro, M. V., Ghivizzani, S. C., and Gibbs, C. P. (2014). Front. Oncol. 4:189. doi: 10.3389/fonc.2014.00189

\section{ACKNOWLEDGMENTS}

This work is supported by National Institutes of Health (NIH) grant

R01 CA137186-04 to Parker
C. Gibbs.

Conflict of Interest Statement: The authors declare that the research was conducted in the absence of any commercial or financial relationships that could be construed as a potential conflict of interest.

Received: 16 December 2014; accepted: 23 December 2014; published online: 14 January 2015.

Citation: Guijarro MV, Ghivizzani CS and Gibbs PC (2015) Corrigendum: Animal models in osteosarcoma. Front. Genet. 5:475. doi: 10.3389/fgene. 2014.00475

This article was submitted to Cancer Genetics, a section of the journal Frontiers in Genetics.

Copyright (c) 2015 Guijarro, Ghivizzani and Gibbs.

This is an open-access article distributed under the terms of the Creative Commons Attribution License (CC BY). The use, distribution or reproduction in other forums is permitted, provided the original author(s) or licensor are credited and that the original publication in this journal is cited, in accordance with accepted academic practice. No use, distribution or reproduction is permitted which does not comply with these terms. 